\title{
An Overview of the Statutory Laws and Regulations Relating to the Maritime Issues of Bangladesh: Loopholes and Recommendations
}

\author{
Muhammad Farhad Hosen \\ Department of Law, International Islamic University, Chittagong, Bangladesh \\ Email: farhadlex@gmail.com
}

How to cite this paper: Hosen, M. F. (2019). An Overview of the Statutory Laws and Regulations Relating to the Maritime Issues of Bangladesh: Loopholes and Recommendations. Beijing Law Review, 10, 1331-1345.

https://doi.org/10.4236/blr.2019.105071

Received: October 23, 2019

Accepted: December 15, 2019

Published: December 18, 2019

Copyright () 2019 by author(s) and Scientific Research Publishing Inc. This work is licensed under the Creative Commons Attribution International License (CC BY 4.0).

http://creativecommons.org/licenses/by/4.0/

(c) (i) Open Access

\begin{abstract}
The research intention is to overview the existing laws and regulations regarding the maritime territory of Bangladesh. In this time demanding research, the researcher tries to point out, the legal circumstance of the sea territory of Bangladesh and how the sea territory is being protected. Where there are more 1350 statutory laws of State but not more than $2 \%$ is directly or indirectly related with the sea territorial concern. Whereas, its total area of sea territory is more than her land territory. Bangladesh geographically situated in shore of the Bay of Bengal. After its independence, it already has passed 48 years but till in this tenure couldn't protect her vast sea territory as like her land boundary due to her two neighboring State's concern and lack of legal and economic management. Last decade, major concerning issues with her two neighboring States already had been dissolved by the interferences of International Tribunal for the Law of Sea and the International Permanent Court of Arbitration. But due to its legal drawbacks, stockholders are not interested to come here as much as required. Here, researcher tries to identify the present legal status of the maritime issue of Bangladesh along its defects and recommendations.
\end{abstract}

\section{Keywords}

Statutory Laws, Maritime Territory, Bangladesh, Loopholes, Recommendations

\section{Background of This Research}

Bangladesh applied its secession to become independent in 1971 by a bloodshed historic war against Pakistan. Historically this territory had been originated in the time of Christen Era; later on it was governed and administered by Hindus, 
Muslim, British and Pakistan successively. Basically, Bangladesh is located in the southeast side of Asia. It has 147,570 square kilometer land territory with its undisputed sea territory (It remains 207,000 square kilometer sea territory); along its, 111,631 square kilometer won from Myanmar by the decision of International Tribunal of the Law of Sea and 19,467 square kilometer won from India by the award of Permanent Court of Arbitration. It has surrounded by two neighboring countries India-Myanmar and Bay of Bengal. India is situated her west, south and partial east sides, Myanmar is located other partial side of east and Bay of Bengal is located her north littoral side. Total surrounding boarder length is about 5000 kilometer. Among this land boarder is 4427 (4156 kilometers with India, 271 kilometers with Myanmar) and 710 kilometers is coastal territory connected with the Bay of Bengal (Belal, 2012).

After the independent, Bangladesh has settled her most of the land boarder issues with India and Myanmar but they couldn't not reach in a final solution of their sea territorial issues though Bangladesh claimed they reached in a peaceful settlement about the maritime issues with India and Myanmar. Although, it has been proved, Bangladesh and Myanmar entered into a mutual Agreed Minutes in 1974 through a number of round table conferences between the State representatives of these two States in Dacca and Rangoon (Case No-16, ITLOS). Later till 2008, they peacefully followed that mutual Agreed Minute of 1974. When in 2008, controversies raised have been raised, then both the States went to the ITLOS in 2009. Finally in March, 2012, their conflict of interests dissolved peacefully and Bangladesh obtained 111,631 square kilometer sea territory by this decision ${ }^{1}$.

After the 35 years settled sea territory between Bangladesh and India in 2006, India disagreed to follow the settled issues of 1974 about their sea territory sharing agreement. India claimed south tal-patti was the territory of India. But, Bangladesh claimed it was her territorial island which was a settled issue between them since 1974. When India disagreed to follow their previous agreed settlement agreement and without any authorization, Indian Ship entered in Bangladesh territory in 2006, and then this two friendly neighboring States mutually went to the Permanent Court of Arbitration in 2009 to settle their maritime boundary. Later, in 2014, Permanent Court of Arbitration gave its award mostly in favor of Bangladesh. Because, from claimed 25,602 square kilometers, Bangladesh got 19,467 square kilometers (The Daily Star, 2014). But South-Talpatti was awarded in favor of India; it is very sad for India that US Survey said that there is no existence of the South-Talpatti in the mouth of Hariyabhanga river.

By this two landmark decisions of ITLOS and Permanent Court of Arbitration, the sea territory of Bangladesh already has been demarcated. If we see the scenario of the legal status of the maritime issue of Bangladesh till 2009, Bangladesh could not enact a comprehensive law to deal the sea territorial matters due to the peaceful sharing with the neighboring States or concerning of them, but it

${ }^{1}$ International Tribunal for the Law of Sea, Hamburg, Germany. 
should also believe that due to the lethargy of the stable rolling party government of Bangladesh, we couldn't enact a comprehensive code for the proper utilization of the sea territory of Bangladesh after the solution of the conflicts with Myanmar and India. We have to run our maritime concern through the old laws. Most of them enacted before the commencement of UNLOS.

\subsection{Research Challenges}

In this research work, researcher tries to conferred all the responsibilities to the legislator of the country to ensure a comprehensive law for the better management of her sea territory, but which is so tough task for the legislator to make such type of comprehensive and codified law. Although, if the country able to enact such type of enactment but application of it will not fully depends only upon it. Neighboring countries cooperation here is a big challenge. Big States are always trying to control the small countries; here Bangladesh might have to be controlled by the India, China, USA or other big power country of the world. Where Bangladesh would be fail to exercise its sovereignty upon its sea territory.

\subsection{Objectives of This Research}

Ultimate objectives of this research are as follows:

1) To find out the existing statutory laws and regulations of Bangladesh regarding the maritime issues;

2) To find out the international laws which are applicable for Bangladesh regarding the maritime issues;

3) To find out the loopholes of the existing laws and regulations of Bangladesh relating to this concern;

4) To give a recommendation for utilization of the sea territory of Bangladesh with the legal environment; and

5) To ensure a legal environment for the investors to invest in maritime territory peacefully.

\subsection{Research Questions}

These are very reasonable questions with this research work:

1) What are the existing constitutional and statuary laws of Bangladesh relating with the maritime issues of Bangladesh?

2) What are the existing international laws regarding the maritime issues applicable in Bangladesh?

3) What are the loopholes of these existing laws regarding the maritime issues?

4) How these laws shall be amended?

5) How a safe legal environment shall be established in this sea territory?

\section{Significance of This Research}

With a view to obtaining the ultimate use of this blue economy, the legislators of 
Bangladesh very shortly should enact a code for the proper management of the sea territory of Bangladesh or the existing laws relating to the maritime boundary should amend immediately. That's why the significance of this research is a time demanding aspect of the people of Bangladesh. To give a peaceful utilization of this boundary we should work very hard; especially for duties and responsibilities vested to the rolling government of the country. If the government can ensure a peaceful environment or sovereignty here, local and foreign investments in this area shall be increased safely and swiftly. To illuminate the future conflict between the two neighboring countries and others who will come here for different socio-economic reasons this research will play a significant rule.

\section{Research Methodology}

The work will be conducted by theoretical analysis and empirical data. For empirical data, national legislation, various types of national and international laws and by-laws, rules and case studies regarding maritime issue will be studied as the primary sources of empirical data. Secondary data will be collected through survey of various documents, books, newspapers, magazines, research articles from different renowned national and international journals as well as several websites related to the research papers. This research will also be basically conducted on the basis of the existing laws national and international laws on maritime issues.

Through this work, researcher will try to mention the existing laws and regulations regarding the maritime territory of Bangladesh. But, by this research some gaps will be come before the viewers. Such as: it will not provide a comprehensive code regarding the management of the sea territory of Bangladesh, it will not possible to ensure the tenure of time when the sea territory shall be safe for all, and finally this research couldn't find out the lacunas and recommendations of the existing international law and regulations regarding the maritime issue though the researcher will try to find out the statutory law's lacunas and recommendations.

\section{Overview of the Present Maritime Laws of Bangladesh}

Inherently Bangladesh is a follower of common law system due to the 200 years' subordination of British Monarch. Therefore, from 1757 to till 1947 this territory was administered through the British regime. In this tenure most of the legal development of this territory was happened. Though, Bangladesh was dominated by Pakistan from 1947 to 1971 there was no remarkable development happened in this territory not only in the legal field but other fields too. After the application of self-determination right of the citizen of East Pakistan, it got independence in 1971. After its independence in 1972 by a Presidential Order No-48 of 1972, the first President of the independent Bangladesh Banghubondhu Shekh Mojibur Rahman commonly known as the Father of Nation of Bangladesh adopted numerous enactments which were earlier passed by the British 
Government and Pakistan Government. Among those laws some were directly and some were indirectly related with the maritime issues of its sovereignty. After the commencement of Bangladesh, there were some laws have been adopted by the legislative organ of the country which is related with the maritime issues of Bangladesh. From 1972-74 Bangladesh and India bilaterally agreed to delimit the sea territory of the Bay of Bengal and Bangladesh and Myanmar entered in a mutually Agreed Minutes in 1974 through which east north side of the Bay of Bengal delimited. After the independence, Bangladesh always tried to show its passion respects toward the international laws, as a result Bangladesh became the member of numerous international organizations and sub-organs of the United Nations. All documents of the United Nations relating to the maritime issues are being followed by Bangladesh. So, as above mentioned and other aspects, we can categories the maritime laws of Bangladesh into five heads:

4.1. Constitution of the Peoples' Republic of Bangladesh, 1972

\subsection{Statutory Laws;}

\subsection{International Laws;}

\subsection{Bilateral agreements; and}

\subsection{Case Laws.}

This work will try to discuss the above mentioned maritime boundary related laws of Bangladesh:

\subsection{Constitution of the Peoples' Republic of Bangladesh}

It's the mother and foundation law of the State which has been adopted in 1972. There are numerous articles of this constitution are directly and indirectly related with the maritime issues of this State; which are as follows:

1) Article-1: This article declares that Bangladesh is a unitary, independent and sovereign country comprising with both the sea territory and land territory and which shall be called as the Peoples' Republic of Bangladesh.

2) Article-2: Article-2 ensures its total territorial boundary including land territory and sea territory. It has been directly indicated, that the territory of East Pakistan which was before the $26^{\text {th }}$ March, 1971 shall be the territory of Bangladesh. As a result the Bengal Commission's Report done by Redcliff of 1947 was considered as the territorial boundary of the newly emerged Bangladesh. And also the newly acquire territory of Bangladesh whether the land or sea shall also be the territory of Bangladesh.

3) Article- 25: This article mentions the foreign diplomatic relationship with the Bangladesh and other States. Here it is directly stated that all the issues relating with the sovereignty of Bangladesh shall be settled in a peaceful settlement means by respecting the international laws. As far this provision we solved our maritime conflicts with India and Myanmar peacefully in 2012 and 2014 respectably.

4) Article- 65: Article-65 empowers the parliament to enact laws for coordinating the State. As per this provision parliament has been vested with the unlimited legislative powers for the well equip maintenance of this country. After the independence, till today parliament enacted several laws to deal the land and sea 
territory of Bangladesh.

5) Article-143(2): It is settled that constitution is the mother law of a State, by which the good governance is occurred. Bangladesh constitution is a well enumerated constitution of the world. Most of the State interest concern has been mentioned here scientifically and precisely. This Article-143 comprehensively tries to specify the maritime concern of the State as following ways-

"1) There shall vest in the Republic, in addition to any other land or property lawfully vested;

a) All minerals and other things of value underlying any land of Bangladesh;

b) All lands, minerals and other things of value underlying the ocean within the territorial waters, or the ocean over the continental shelf, of Bangladesh; and

c) Any property located in Bangladesh that has no rightful owner.

2) Parliament may from time to time by law provide for the determination of the boundaries of the territory of Bangladesh and of the territorial waters and the continental shelf of Bangladesh". 2

According to this Article it is hence settled that, all the territory of Bangladesh has been vested upon to the Republic; elaborately it has been identified here all minerals and other valuable underlying properties; all lands and other properties of the ocean within the territorial waters, ${ }^{3}$ continental shelf ${ }^{4}$. It also mentioned here that the Parliament time to time may enact laws to determine the territory including land and sea (territorial waters and continental shelf etc.).

6) $3^{\text {rd }}$ Amendment of the Bangladesh Constitution: The Land Boundary Agreement was signed on 16 May 1974 between Indira Gandhi of India and Sheikh Mujibur Rahman of Bangladesh which provided for the exchange of enclaves and the surrender of adverse possessions (Jason, 2007). ${ }^{5}$ Till today, Bangladesh Constitution has been amended seventeen times. Among them third amendment dated on November 28, 1974 which was fully concerned with the Indira Gandhi and Sheikh Mujibur Rahman meeting on the territorial boundary settlement between this two States. Through this process land boundary settled amicably but maritime boundary could not settled documentarily like as the land boundary.

\subsection{Statutory Laws}

There are a lot of statutory laws regarding maritime issues; those are for the ${ }^{2}$ Article-143, The Constitution of the People's Republic of Bangladesh, 1972.

${ }^{3}$ The term territorial waters is sometimes used informally to refer to any area of water over which a state has jurisdiction, including internal waters, the territorial sea, the contiguous zone, the exclusive economic zone and potentially the continental shelf. In a narrower sense, the term is used as a synonym for the territorial sea.

${ }^{4} \mathrm{~A}$ continental shelf is a portion of a continent that is submerged under an area of relatively shallow water known as a shelf sea. Much of the shelves were exposed during glacial periods and interglacial periods. The shelf surrounding an island is known as an insular shelf.

${ }^{5}$ Cons, Jason (October 2007). “The Tin Bigha corridor 15 years on”. Forum. The Daily Star. 2 (9). Retrieved 5 June 2017. India will retain the southern half of South Berubari Union No. 12 ... in exchange Bangladesh will retain the Dahagram and Angarpota enclaves. India will lease in perpetuity to Bangladesh an area ... to connect Dahagram with ... Bangladesh. 
proper administration of the maritime boundary of Bangladesh. The following statutory laws which are directly or indirectly relevant with the sea territory of Bangladesh:

1) The Mines Act, 1923: ${ }^{6}$ This enactment was passed in the time of British period later on Bangladesh has adopted this enactment by the Presidential Order. The ultimate objective of this law, is to amend and consolidate the laws relating to the regulation and inspection of mines of the territory of Bangladesh including both land and sea territory.

2) The Companies (Foreign Interests) Act, 1918: This act has been enacted to take power to prohibit the alteration, except with the sanction of the Government, of articles of association which restrict foreign interests in certain companies and to provide for the purposes connected therewith. ${ }^{7}$ Basically this enactment has been enforced to control those companies who are connected with the destructive acts and against the sovereignty of Bangladesh. Till now Bangladesh couldn't develop in the field of technologies. Except the works of BAPEX ${ }^{8}$, most of the invention of Gas, Oil and other natural resources are being done by the foreign companies. So, to manage them this enactment was adopted in 1923.

3) Naval Armament Act, 1923: ${ }^{9}$ Naval Armament Act, 1923 was adopted in London for the purposes to give effect in Bangladesh to the treaty for the Limitation of Naval Armaments and for the exchange of the information concerning the naval construction. Under this act none can build any vessel of war, or alter, arm or equip any ship so as to adapt her as a vessel of war except by the license of Bangladesh Government. Who shall fail to follow the provisions of this act can be punished under this act. It's to be believed that this enactment was also adapted to safe the maritime boundary of the country.

4) The Carriage of Goods by Sea Act, 1925: On the basis of the International Conference on Maritime Law held at Brussels in October, 1922, the delegates at the Conference, including the delegates representative of this territory, agreed unanimously to recommend their respective Governments to adopt as the basis of a convention a draft convention for the unification of certain rules relating to bill of lading; and this convention especially contained provisions relating to establish the responsibilities, liabilities, rights, and immunities attaching the Carriage of Goods by Sea. ${ }^{10}$

5) Sale of Goods Act, 1930: Sale of Goods Act, 1930 specially discusses about the sale of moveable property. This act not directly connected with the maritime issues of Bangladesh but indirectly it plays a huge role. Because, most of our exports or imports related functions are performed by the sea territory. So, impliedly this enactment is inter-related with the maritime issues of the country.

6) The Foreign Relation Act, 1932: This enactment prohibits making any

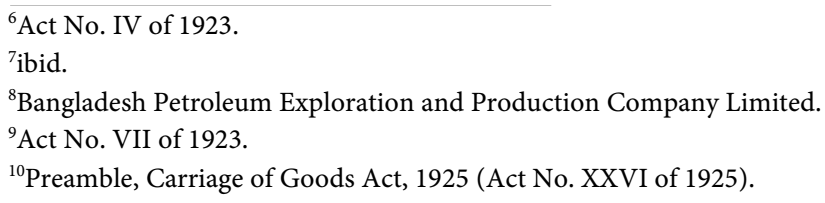


publication of statements likely to prejudice the maintenance of friendly relations between the Government of Bangladesh and the Government of the foreign States relating to any matters including land territory and sea territory. ${ }^{11}$

7) The Registration of Foreigners Act, 1939: There are more than twenty lack foreigners are living in this country for numerous reasons. All of them must be registered under this act to the Foreign Ministry of Bangladesh. We know that, we are fully reliant on the foreigner for exploring gas, oil and other natural resources. Who are coming here to this purpose or others they must have to register themselves. Recently a lot of foreigners have been caught by the law enforcing agencies because of their unauthorized entrance and illegal casino business.

8) The Foreigners Act, 1946: Foreigners who are coming in Bangladesh for any reasons, they shall be controlled by the Government of Bangladesh as specified in the statutory laws of the country. If Government wish then allow any person to this land or sea territory, or not can ensure the departure of that foreigner.

9) Navy Ordinance, 1961: This enactment has been adopted in 1961, by the Pakistan Martial Government. There are more than ten law enforcing agencies of Bangladesh among them only Navy working to secure the sea territorial sovereignty of the State. To manage the naval force, this enactment has been adopted.

10) The Petroleum Products (Development Surcharge) Ordinance, 1961: This enactment has been adopted for the levy and collection of a developed surcharge on petroleum products and the matters connected therewith. In this act petroleum products indicated all types of petroleum identified from land territory of sea boundary. ${ }^{12}$

11) The Excise Duty on Minerals (Labor Welfare) Act, 1967: This act embodied to impose a duty of excise on certain minerals for financing measures for promoting the welfare of labor employed in the mining industry whether the land territory or sea boundary and to provide for the administration and utilization of the proceeds of such duty and for matters ancillary thereto. ${ }^{13}$

12) Territorial Waters and Maritime Zones Act, 1974: The Territorial Water and Maritime Zones Act, 1974 is the mother law of the maritime boundary of Bangladesh. The ultimate objectives of this act are to fulfill the constitutional obligations which have been specified in Article-143(2). ${ }^{14}$ This law tried to give some ideas on the territorial waters, contiguous zone, economic zones, conservation zone, continental shelf and control of the pollution and ecological balance from the territorial water to the high sea.

13) The Bangladesh Petroleum Act, 1974: This act ensures the exploration,

\footnotetext{
${ }^{11}$ Preamble, The Foreign Relation Act, 1932 (Act No. XII of 1932).

${ }^{12}$ Preamble, The Petroleum Products (Development Surcharge) Ordinance, 1961 (Act No. XXV of 1961).

${ }^{13}$ Preamble, The Excise Duty on Minerals (Labour Welfare) Act, 1967 (Act No. VIII of 1967).

${ }^{14}$ The Constitution of the Peoples' Republic of Bangladesh, 1972.
} 
development, exploitation, production, processing, refining and marketing of the petroleum which is emerged from the land territory and sea territory.

14) The Inland Shipping Ordinance, 1976: By this ordinance the Government may ensure the survey, registration and control of the navigation of vessels plying on the inland waters of the maritime boundary of Bangladesh.

15) The Foreign Private Investment (Promotion and Protection) Act, 1980: For the economic interests of the global village, foreign investments are increasing gradually to this subcontinent. This enactment has been adopted by the Bangladesh Government to enhance and ensure the safe environment the foreign private investment in this country in both the land territory and sea territory along with other fields. As a result our most of the gas and oil exploring company came from the foreign private sources.

16) Bangladesh Flag Vessels (Protection) Ordinance, 1982: By this enactment Bangladeshi Flag Vessels are being protected. On the other hand, it imposes restrictions on the other country's vessels who do not owe their sovereign flag in this sovereignty.

17) Marine Fisheries Ordinance, 1983: This enactment has been adopted to make the provisions for the control, management, conservation and development of the marine fisheries of Bangladesh.

18) The Foreign Voluntary Organizations (Acquisition of Immovable Property) Regulation Ordinance, 1983: Through this act Government of Bangladesh control, permit, manage and restricts upon to the foreign voluntary association who are working for the interest of human being economically or by protecting the maritime pollution.

19) The Bangladesh Oil, Gas and Mineral Corporation Ordinance, 1985: By this enactment a corporation has been establish as namely- Bangladesh Oil, Gas and Mineral Corporation for embodied the gas, oil and mineral resources from the land territory and sea territory. Corporation does research, implement program, produce and sell and such other functions as the govt. desires to perform in the field of gas, oil and minerals resources of the country.

20) Water Resources Planning Act, 1992: In 1992, Bangladesh Government enacted this act to control and protect water, and also to utilize this water for the well-being of the country.

21) Mine and Mineral Resources (Control and Development) Act, 1992: This enactment has been adopted for the proper utilization, control, preservation, research and development of the mine and mineral resources of the land and sea territory of Bangladesh.

22) Bangladesh Preservation of Environment Act, 1995: Bangladesh Preservation of Environment has been adopted to protect the environment of Bangladesh, to ensure the sound and healthy environment, and to control the pollution of the environment of the country including both land and sea territory.

23) Admiralty Court Act, 2000: Admiralty Court is equivalent to the High Court Division of the Supreme Court of Bangladesh, which is situated in the Supreme Court premises in Dhaka. Violations of the maritime issues are under the 
prosecution to this Admiralty Court.

24) Bangladesh Shipping Corporation Ain, 2017: To ensure the safe shipping zone in Bangladesh under the national and international laws vested upon the Bangladesh Shipping Corporation which has been established under this act.

These are the present statutory laws of Bangladesh through which maritime issues of Bangladesh are trying to be resolved.

\subsection{International Laws}

Apart from the national instruments Bangladesh signed various international instruments which are directly or indirectly relevant with the maritime issues. Since the adoption of its constitution, Bangladesh tried to uphold the international laws. ${ }^{15}$ The following international laws have been signed by Bangladesh to manage the maritime issues:

1) Convention of the United Nations: On $17^{\text {th }}$ September, 1974 United Nations declared Bangladesh as an independent State and Bangladesh became its 136 number member State. As a result Bangladesh became the duty bound of the UN Charter, 1945. Under the binding effects of the Charter Bangladesh tries to negotiate the land and sea territorial concern with it neighboring States for ensuring peace and security of the world. ${ }^{16}$

2) Vienna Convention on the Law of Treaties, 1969: Bangladesh is a signatory State of the Vienna Convention on the Law of Treaties, 1969. In the Bangladesh v. Myanmar Case regarding the maritime issues in ITLOS, where Bangladesh referred the binding effects of this treaty in both the land and sea territorial disputes between two sovereign States.

3) UNCLOS: UNCLOS ${ }^{17}$ is considered as a Constitution of the Sea Law. There are three UNCLOS documents likely- UNCLOS-I of 1956, UNCLOS-II of 1960 and UNCLOS-III of 1982. In 2001 Bangladesh signed these documents and became the Member State of these UNCLOS. As far this documents Bangladesh settled the maritime dispute with Myanmar in 2012. We should also rectify that, UNCLOS plays most important role as the source of international law regarding the maritime issues of Bangladesh.

\subsection{Bilateral Agreements}

Basically two bilateral agreements of Bangladesh upon which they peacefully enjoyed the Bay of Bengal with her two neighboring States, these documents are:

1) Mutual Agreed Minutes of 1974 and 2008 between Bangladesh and Myanmar: Bangladesh and Myanmar both were the control of British till 1947, later Myanmar got independence first in 1947 and the territory of Bangladesh accompanied to the territory of Pakistan as calling this territory as the East Pakistan. Before giving sovereignty British Government settled the territorial area through the Bengal Commission done by Redcliff in 1947. Till 1971, Myanmar

${ }^{15}$ Article-25, Constitution of the People's Republic of Bangladesh, 1972.

${ }^{16}$ Article-33, Charter of the United Nations, 1945.

${ }^{17}$ United Nations Conventions on the Law of Sea. 
and Pakistan peacefully enjoyed both sea and land territory. After emerging of Bangladesh, both the States again demarcated their sea territorial boundary through a bilateral agreement which is called as the Mutual Agreed Minutes 1974. Later in 2008 Myanmar denied to enforce this agreement and partially they settled their issue in 2008. So far as it is called another Agreed Minutes of 2008. But they couldn't fulfill the conditions of this document and finally went to the ITLOS $^{18}$ in 2009.

2) Bangladesh and India Bilateral Agreement, 1972: There were multiple rounds table conferences between Bangladesh and India for bilateral negotiation to agree upon sea territorial boundary delimitation between 1974 and 2009. But couldn't reach in a final solution. In this period of time, they settled their maritime boundary through the bilateral settlement of New Moor Island is the last line of India and South Talpatti Island is the Bangladesh (Rosen \& Jackson, 2017). This is the bilateral agreement between Bangladesh and India relating with their sea territory (Rosen $\&$ Jackson, 2017). ${ }^{19}$

\subsection{Case Laws}

Precedent is binding upon to the State under the domestic and international laws of Bangladesh. Last decade, Bangladesh got two remarkable decisions on the sea controversies against the Myanmar and India. These two cases shortly discuss here:

1) Case No-16 of ITLOS between Bangladesh and Myanmar, 2012: After more than 35 years peaceful enjoyment of the Bay of Bengal by the two neighboring countries Bangladesh and Myanmar, they mutually moved to the ITLOS in 2009 for settling their newly emerged maritime disputes. After about two years proceeding, the Tribunal announced her judgment in March, 2012. On the decision of the Tribunal both the parties expressed their satisfaction. This judgment shall hold as one of the most important source of the Law of precedent for both the States to refrain them from future conflict on the maritime issue.

2) Award of the Permanent Court of Arbitration regarding Bangladesh and India, 2014: Another important case law for the Bangladesh and India is the award of the Permanent Court of Arbitration, 2014 regarding the maritime dispute between these two States (Award, 2014). ${ }^{20}$ Under the peaceful settlement of 1974, South Talpatti was considered as the territory of Bangladesh but from 2006 India claimed that this territory is her. Then these two friendly neighboring States went in to the arbitration at the Permanent Court of Arbitration in 2009. In 2014 the Court pronounced her Award. Eminent on this field says that Bangladesh won this award because from 25,602 square kilometer Bangladesh won 19,467 square kilometers. This judgment is another source of the case law re-

\footnotetext{
${ }^{18}$ International Tribunal for the Law of Sea, Hamburg, Germany.

${ }^{19}$ https://www.cna.org/c na_files/pdf/DOP-2017-U-016081-Final.pdf visited on September 23, 2019

${ }^{20}$ Bay of Bengal Mar. Boundary Arbitration (Bangl. v. India), (Perm. Ct. Arb.2014), Paragraph 56, accessed Aug. 17, 2017, https://pcacases.com/web/sendAttach/383 (Hereinafter Bangladesh v. India or "the Award" depending on context).
} 
garding maritime issues of Bangladesh and India and they have to mandatorily obey the decision of this court.

Above discussed provisions of the Constitution, Statutory Laws, bilateral agreements and case laws are the existing laws and regulations of the maritime boundary of Bangladesh. But, this work thinks, this existing laws and regulation are not well equipped on these highly concern issues of the today's world.

\section{Drawbacks and Recommendations}

There are a lot of lacunas of the existing laws and regulations of the maritime laws of Bangladesh, for which the maritime boundary of the country couldn't utilize properly. Followings are the major loopholes related with the maritime boundary of Bangladesh:

1) Till now the Government of Bangladesh couldn't enact a code for the maritime issues of Bangladesh; the Government of Bangladesh couldn't fulfill the Constitutional provisions of the Article-143(2); and Bangladesh couldn't fulfill the rules and regulations of UNCLOS;

2) There is no exclusive Maritime Court has been established in Bangladesh though its maritime boundary is more than its land territory;

3) Government couldn't stop the human trafficking and smuggling through this maritime boundary;

4) There is no specialized research center in Bangladesh to pursue research in these maritime issues;

5) No sufficient technology to explore the mineral resource areas from this maritime boundary;

6) Laws relating to the foreign investments in these sectors are so weak, old and insufficient for increasing investments in this sector;

7) Near about, one decade has been passed of the two remarkable decisions of International Tribunal for the Law of Sea and Permanent Court of Arbitration Bangladesh couldn't complete the survey for fixing its area of baseline, territorial waters, exclusive economic zone;

8) After these two decisions Bangladesh couldn't stop the unauthorized entrance of the Fishing Ships, fisher-men and Cargoes of the neighboring States;

9) Bangladesh couldn't control the environmental pollution of her maritime zone;

10) In this huge territory Bangladesh couldn't establish a safe zone for fisheries in her territory;

11) Saint Martin Island, Nizum Island, Andar Manik Islad, Hatiya and other Islands of the country are the great asset for the Sovereignty, which are located in the maritime boundary of Bangladesh but Govt. couldn't develop it properly; that indicates that the Government failed to use its maritime boundary commercially and economically;

12) Lack of the social awareness programs, seminar, symposiums, workshops relating to the proper utilization of the maritime boundary of Bangladesh;

13) There are no sufficient educational institutions relating to the maritime 
concern of Bangladesh;

14) Punishments which have been mentioned in different laws relating to the maritime field are insufficient;

15) In Bangladesh, there are no adequate modern technologies for exploitation of mineral resources from its maritime zone;

16) State has no sufficient concern about this territory due to this reason power occupied countries of the word are trying to control this domain;

17) Foreign relationship between the two neighboring States is not faithful enough for maintaining a safe and sovereign maritime zone of Bangladesh.

To ensure a safe and sovereign maritime zone Bangladesh as early as possible should follow the following mentioned recommendations:

1) The rolling government of the country should immediately by complying the provisions of the Article- $143^{21}$ adopt a comprehensive code regarding the maritime issues;

2) Bangladesh government should take necessary actions to implement the provisions of the UNCLOS ${ }^{22}$, decision of the ITLOS $^{23}$ of Bangladesh v. Myanmar case, and the decision of $\mathrm{PCA}^{24}$ of Bangladesh v. India arbitration.

3) Government should take steps for establishing maritime court as required to ensure the peace and security of this maritime boundary and to control the unauthorized human trafficking, smuggling and environment pollution through her maritime zone;

4) Should introduce some research institutions for legal and scientific utilization of this maritime boundary along with establishing educational institutions for theoretical education on this field;

5) Government of Bangladesh should immediately ensure a survey for delimit the maritime boundary of the Bangladesh on the basis of $\mathrm{UNCLOS}^{25}$, decision of the ITLOS of Bangladesh v. Myanmar case, and the decision of PCA of Bangladesh v. India arbitration;

6) Government should use the modern technology by which he can explore the zones of the mineral resources and fisheries of this area;

7) Saint Martin Island, Nizum Island, Andar Manik Islad, Hatiya and other Islands of the country and the all ports of Bangladesh should utilize commercially and economically;

8) If not possible to enact a code immediately, the Government should amend the present laws regarding this issues; and especially govt. should sincere more to control the foreign investors in this field legally;

9) Foreign policy if requires should change to increase the Government sovereignty upon this long maritime territory;

10) Finally, govt. should patronize the individual whether natural or artificial person who are interested to work for the development of the maritime territory

${ }^{21}$ Constitution of the Peoples' Republic of Bangladesh, 1972.

${ }^{22}$ United Nations Conventions on the Law of Sea.

${ }^{23}$ International Tribunal for the Law of Sea, Hamburg, Germany.

${ }^{24}$ Permanent Court of Arbitration, Hague, Netherlands.

${ }^{25}$ United Nations Conventions on the Law of Sea. 
of this sovereignty.

\section{Conclusion}

Bangladesh government tries to ensure her sovereignty to the maritime boundary of Bangladesh as like her land territory but as new arising and floated government it is going to tough for the State. After its commencement, govt. introduced there are various laws and regulations for managing its maritime boundary. But due to time, place, situation and occurrences those laws lost their time demanding values. Two neighboring States and super power States of the world are interested a lot to this maritime boundary because of its huge natural resources.

Researcher tried to discuss the present legal conditions of the maritime boundary of the sovereign State of Bangladesh. This research has created scope of some further researches, likely: on the Future Laws and Regulations regarding the Maritime Boundary of Bangladesh; on the Evaluation of the Maritime Boundary case between Bangladesh and Myanmar: Case No-16 of ITLOS-2011; on the Exploitation and Legal Protection of the newly Emerged Sea Territory of Bangladesh; An Evaluation of the Maritime Conflict between Bangladesh and India: Decision of the ICA-2014; on the Rules and Regulations regarding the foreign investment for raising natural resources from the Maritime Boundary of Bangladesh; An approach to identify the Sovereignty of a State in Maritime Boundary and Land Territory: Bangladesh Perspective, etc. can be the new area of further research.

Now, as early as possible, the government of Bangladesh should introduce new laws and regulations for imposing restrictions to the unauthorized interferences of the foreign States and to utilize this maritime boundary economically and commercially.

\section{Conflicts of Interest}

The authors declare no conflicts of interest regarding the publication of this paper.

\section{References}

Admiralty Court Act, 2000.

Bangladesh Preservation of Environment Act, 1995.

Bay of Bengal Mar. Boundary Arbitration (Bangl. v. India), (Perm. Ct. Arb.2014), Paragraph 56, Accessed Aug. 17, 2017. (Hereinafter Bangladesh v. India or "the Award" Depending on Context) https://pcacases.com/web/sendAttach/383

Belal, A. S. M. (2012). Maritime Boundary of Bangladesh: Is Our Sea Lost? Bangladesh Institute of Peace and Security Studies.

International Tribunal for the Law of Sea, Hamburg, Germany (2012). Judgment, Bangladesh v. Myanmar Case, Case No. 16.

International Tribunal for the Law of Sea, Hamburg, Germany (2012). Judgment, Ban- 
gladesh v. Myanmar Case, Case No. 16 (pp. 24-35).

Permanent Court of Arbitration, Hague, Netherlands (2014). Award, Bangladesh v. India Arbitration.

Preamble, the Petroleum Products (Development Surcharge) Ordinance, 1961 (Act No. $X X V$ of 1961).

Rosen, M. E., \& Jackson, D. (2017). Bangladesh v. India: A Positive Step forward in Public Order of the Seas, CAN, September (p. 3).

Sale of Goods Act, 1930 (Act No. III of 1930).

Territorial Waters and Maritime Zones Act, 1974.

The Constitution of the Peoples' Republic of Bangladesh, 1972.

The Excise Duty on Minerals (Labor Welfare) Act, 1967 (Act No. VIII of 1967).

United Nations (1983). United Nations Conventions on the Law of the Sea (UNCLOS): Official Text. New York.

Vienna Convention on the Law of Treaties, 1969.

Water Resources Planning Act, 1992.

https://www.cna.org/cna_files/pdf/DOP-2017-U-016081-Final.pdf 